\title{
NON-PANCREATIC LIPASE IN CHILDREN WITH PANCREATIC FIBROSIS
}

\author{
BY \\ CONSTANCE A. C. ROSS and H. G. SAMMONS \\ From the Department of Paediatrics and Child Health and the Department of Pharmacology, \\ University of Birmingham
}

(RECEIVED FOR PUBLICATION APRIL 18, 1955)

It has been shown that children with pancreatic fibrosis who have no pancreatic lipase at all may absorb a considerable proportion of dietary fat (Shohl, 1948; Andersen, 1945a and b; Ross, 1955). In addition it has been demonstrated by Andersen (1945a) that there may be a considerable amount of hydrolyzed fat in the stools of children with pancreatic fibrosis. These findings would indicate the presence of non-pancreatic lipase in the gastrointestinal tract derived either from dietary or nondietary sources.

Possible sources of dietary lipase have not been adequately investigated. Although Green (1890) demonstrated lipase in the germinating seeds of the castor bean, we could find no reports on the lipase content of various fresh fruit and vegetables which are commonly used in human diets. Freudenberg (1929) showed that there was lipase in human and cow's milk and claimed that the enzyme in milk was activated by a lipokinase in human gastric juice. Several possible sources of non-dietary lipase in the gastro-intestinal tract have been studied. Schønheyder and Volqvartz (1944) demonstrated lipase in both gastric juice and gastric mucosa from infants and adults: they showed that only the lower triglycerides were hydrolyzed to an appreciable degree by this lipase and that the optimum $p \mathrm{H}$ was $5 \cdot 5$ to $5 \cdot 8$. It has been questioned, however, if gastric lipase is secreted by the stomach or if it enters the stomach by regurgitation from the duodenum (Wolman, 1943). That intestinal bacteria might be a source of lipase in children with pancreatic fibrosis was suggested by Andersen (1945a) who found that a considerable degree of hydrolysis of faecal fat occurred in stools which were left standing for 48 hours at room temperature.

The object of the present study was to investigate the activity of several possible sources of dietary and non-dietary lipase in the gastro-intestinal tracts of children with pancreatic fibrosis.

\section{Materials and Methods}

Estimation of Lipase. To $5 \mathrm{ml}$. of phosphate buffer containing $0.5 \%$ bile salts at $p \mathrm{H} 7.8$ in a 50 -ml. stoppered conical flask was added $1 \mathrm{ml}$. of acid-free olive oil. The lipase preparation was then added and the mixture shaken for 30 minutes at $37^{\circ} \mathrm{C}$. It was then acidified and extracted with $20 \mathrm{ml}$. of benzene. A 10-ml. sample of upper benzene layer was titrated with $0.05 \mathrm{~N}$ tetramethylammonium hydroxide in alcohol. A control was made in the same way but with the addition, before digestion, of a few drops of concentrated hydrochloric acid to inhibit lipase activity. The titration figure in ml. gave the units of lipase in the sample (Frazer, Sammons and Thompson, 1955). As it was found that the error of this method was \pm 0.05 units, any reading below 0.1 was considered as nil.

Dietary Lipase. Lipase was estimated in the following items of diet.

MILK. Both human and cow's milk were investigated: representative specimens of human milk were obtained from the whole milking of each of 12 mothers at varying stages of lactation; similar specimens were obtained from six cows. Each specimen was thoroughly mixed and its lipase content estimated before and after pasteurization.

FRUITs. These comprised apple, banana, pear, orange and tomato: $1 \mathrm{~g}$. of each, finely chopped, was used for the estimation.

Non-dietary Lipase. Specimens of faeces and gastric juice were obtained from seven children with pancreatic fibrosis who had not received pancreatin during the preceding four days. Each child had no pancreatic enzymes whatever in duodenal juice: lipase was estimated by the method described above, trypsin by the method of Tomarelli, Charney and Harding (1949). The fat absorption figures in these children ranged from 32 to $60 \%$ of their dietary fat intake: fat absorption was assessed by fat balance studies for periods of five to 10 days, faecal fat being measured daily by an adaptation of the fatty acid method of Kamer, Bokkel Huinink and Weyers (1949) as described by Anderson, Frazer, French, Gerrard, Sammons and Smellie (1952).

FAECES. As we found that lipase was rapidly destroyed 
in faeces at room temperature, a complete fresh stool collection was obtained from each child. This was immediately homogenized with water to a known volume and lipase estimations were carried out on 1-ml. samples of each homogenate.

GASTRIC JUICE. A specimen was obtained from the fasting child and was kept at $0^{\circ} \mathrm{C}$. Lipase was estimated in $\mathbf{0 . 1} \mathrm{ml}$. of gastric juice within two hours of collection. As we found that gastric lipase activity, using olive oil as

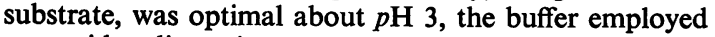
was acid sodium citrate at $p \mathbf{H} \mathbf{3 \cdot 0}$.

Cultures of Intestinal Bacteria. Cultures of various intestinal bacteria (Esch. coli, $\beta$-haemolytic Streptococcus, Streptococcus faecalis, Streptococcus viridans and Staphylococcus aureus) were obtained from the faeces of a child with pancreatic fibrosis. A specimen of the faeces was plated on blood agar, on blood agar after treatment of the faeces with toluene to suppress the Gram-negative organisms and on MacConkey's agar. After incubation for 24 hours at $37^{\circ} \mathrm{C}$., representative individual colonies were picked off and subcultured in (a) glucose broth and $(b)$ glucose broth containing $0.5 \%$ nut oil. After incubation for 18 hours at $37^{\circ} \mathrm{C}$., $1 \mathrm{ml}$. of each subculture was used for estimation of lipase. This method would, of course, only detect exo-lipase and not endo-lipase in bacterial cells: it was considered, however, that bacterial endo-lipase would not be concerned in digestion.

Chylomicrographs. Counts of the fat particles in the blood after a standard fat meal were carried out by the chylomicrograph technique described by Frazer and Stewart (1939): details of the procedure have been given in a previous report (Ross, 1955).

\section{Results}

Dietary Lipase. This was demonstrated as follows:

MiLK. The lipase content of the samples of human milk is shown in Table 1 and of the samples of cow's milk in Table 2. In the unpasteurized samples of human milk the lipase ranged from 0.35 to 0.95 units per $1 \mathrm{ml}$. (mean 0.56 units) compared

TABLE 1

LIPASE IN HUMAN MILK

\begin{tabular}{c|c|c|c}
\hline \multirow{2}{*}{ Mother } & $\begin{array}{c}\text { Week of } \\
\text { Lactation }\end{array}$ & \multicolumn{2}{|c}{ Lipase (units per 1 ml.) } \\
\cline { 3 - 4 } & Unpasteurized & Pasteurized \\
\hline 1 & 1 & 0.4 & 0 \\
2 & 1 & $0 \cdot 5$ & 0 \\
3 & 1 & 0.75 & 0.1 \\
4 & 3 & 0.95 & 0.1 \\
5 & 4 & 0.8 & 0 \\
6 & 5 & 0.4 & 0 \\
7 & 6 & 0.4 & 0.2 \\
8 & 8 & 0.8 & 0.1 \\
9 & 10 & 0.35 & 0 \\
10 & 11 & 0.5 & 0 \\
11 & 15 & 0.4 & 0 \\
12 & 16 & 0.5 & 0.04 \\
\hline
\end{tabular}

TABLE 2

LIPASE IN COW'S MILK

\begin{tabular}{c|c|c}
\hline \multirow{2}{*}{ Cow } & \multicolumn{2}{|c}{ Lipase (units per 1 ml.) } \\
\hline & Unpasteurized & Pasteurized \\
\hline 1 & $0 \cdot 1$ & 0 \\
2 & $0 \cdot 1$ & $0 \cdot 1$ \\
3 & 0 & 0 \\
4 & 0 & 0 \\
5 & 0 & 0 \\
6 & $0 \cdot 3$ & 0 \\
\hline
\end{tabular}

with a range of 0 to 0.3 in the unpasteurized samples of cow's milk. After pasteurization there was a considerable reduction in the lipase content of both human and cow's milk samples. Moreover, it was found that there was a rapid loss of milk lipase at room temperature: in a sample of human milk at $17^{\circ} \mathrm{C}$. the lipase fell from 0.53 units at the time of collection from the breast to 0.26 units at four hours and $0 \cdot 18$ units at nine hours.

Evidence that the lipase in fresh unpasteurized human milk may increase fat absorption in pancreatic fibrosis was obtained as follows. Chylomicrographs were carried out on an infant with this disease after feeds, quantitatively similar in fat content, of (a) unpasteurized human milk, (b) pasteurized human milk and (c) pasteurized cow's milk. From Fig. 1 it will be seen that the chylomicrograph after

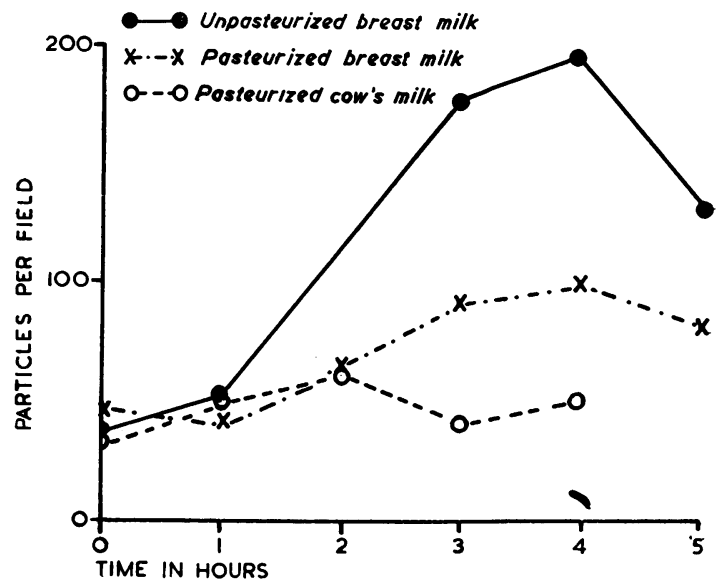

FIG. 1.-Chylomicrographs after milk feeds quantitatively similar in fat content, in a boy 8 months of age with pancreatic fibrosis.

unpasteurized human milk showed a higher rise than those obtained after pasteurized human milk or pasteurized cow's milk. Unfortunately we were unable to confirm this finding by fat balance studies in a baby receiving fresh unpasteurized human milk as there was no breast-fed baby in the present series, nor could we obtain a completely fresh supply of 
human milk for the $\mathbf{1 0}$ days necessary for a fat balance study.

FruITs. No lipase was detected in any of the fruits examined.

Non-dietary Lipase. The following gave useful results:

FaEces. From Table 3 it will be seen that lipase

TABLE 3

LIPASE IN FAECES OF CHILDREN WITH PANCREATIC FIBROSIS

\begin{tabular}{|c|c|c|c|c|}
\hline \multirow{2}{*}{ Patient } & \multirow{2}{*}{$\begin{array}{c}\text { Age } \\
\text { (yrs.) }\end{array}$} & \multirow{2}{*}{$\begin{array}{c}\text { Mean } \\
\text { Percentage } \\
\text { Fat } \\
\text { Absorption }\end{array}$} & \multicolumn{2}{|c|}{ Faecal Lipase (units) } \\
\hline & & & $\begin{array}{c}\text { Per } 1 \mathrm{ml} \text {. } \\
\text { Homogenate }\end{array}$ & $\begin{array}{l}\text { Per } 100 \mathrm{ml} . \\
\text { Fresh Faeces }\end{array}$ \\
\hline $\begin{array}{l}1 \\
2 \\
3 \\
4 \\
5 \\
6 \\
7\end{array}$ & $\begin{array}{l}1 \frac{1}{2} \\
1 \frac{1}{8} \\
3 \frac{1}{2} \\
4 \\
4 \\
5 \\
6\end{array}$ & $\begin{array}{l}52 \\
48 \\
52 \\
39 \\
58 \\
32 \\
60\end{array}$ & $\begin{array}{l}0 \cdot 53 \\
0 \cdot 21 \\
0 \cdot 1 \\
0 \cdot 44 \\
0 \cdot 64 \\
0 \cdot 58 \\
0 \cdot 10\end{array}$ & $\begin{array}{r}106 \\
53 \\
27 \\
88 \\
134 \\
174 \\
24\end{array}$ \\
\hline
\end{tabular}

was present in the faeces of all seven children. The possible sources of this enzyme seemed to be gastric juice, intestinal bacteria and succus entericus.

GaSTRIC JUICE. No lipase was found in five out of the seven samples of fasting juice; the remaining two samples contained only traces of lipase- 0.23 and $0 \cdot 12$ units respectively. From this it would appear that gastric juice provides no significant contribution to gastro-intestinal lipase.

INTESTINAL BACTERIA. No lipase was detected in any of the cultures under the conditions of the experiment either in glucose broth or glucose-oil broth.

\section{Discussion}

We have shown that, of various fresh foods commonly used in human diets, only unpasteurized milk contained lipase and that this enzyme was appreciably greater in human than in cow's milk. It was found that milk lipase was destroyed by pasteurization and that its activity decreased rapidly at room temperature. That the lipase in fresh human milk may play a part in lipolysis was suggested by the chylomicrograph findings after various milk feeds in an infant with pancreatic fibrosis: the chylomicronaemia was significantly greater after a feed of unpasteurized human milk than after feeds of either pasteurized human milk or pasteurized cow's milk. This would suggest that breast-fed infants with pancreatic fibrosis might have a greater fat absorption and hence more favourable nutrition than babies with pancreatic fibrosis who are artificially fed. Andersen (1938) and Lowe, May and Reed (1949), however, could find no difference between the nutritional state, as judged by weight gain, of breast-fed and artificially-fed babies with pancreatic fibrosis. In the present series of children with pancreatic fibrosis all were receiving pasteurized cow's milk preparations so that dietary lipase would play a negligible role in intestinal lipolysis.

We have shown that lipase is present in fresh faeces from children with pancreatic fibrosis. Its absence or presence in minute amounts in gastric juice from these children indicates that gastric juice is not an appreciable source of the enzyme. In addition, we have demonstrated that no exo-lipase was produced in cultures of several intestinal organisms from a child with pancreatic fibrosis. The lipase activity of 1,000 strains of 18 potentially pathogenic genera was investigated by Davies (1954) who found that only certain strains of staphylococci produced exo-lipase: she assessed lipase activity by demonstrating either a zone of clearing on a culture plate of nutrient fat agar or a blue zone on a plate of nutrient fat Nile blue sulphate agar. Our inability to demonstrate production of exolipase by the Staphylococcus aureus in the present study might be due to the fact that this strain belonged to the group from which Davies could detect no lipase production; on the other hand, her method of estimation might be more sensitive than ours. It is evident, however, that intestinal organisms are not an appreciable source of faecal lipase. Moreover, as fat absorption occurs in the small intestine and intestinal organisms are mainly limited to the large intestine (Cregan and Hayward, 1953), it is obvious that bacterial lipase would play little part in lipolysis of dietary fat. It seems that the enzyme is probably derived from the succus entericus: this deduction finds support in recent work by Singer, Sporn and Necheles (1954), who have shown, in dogs, that lipase is secreted by the jejunum.

Sammons, Ross and Wood (1955) have demonstrated the presence of a proteolytic enzyme in the stools of children with pancreatic fibrosis. They showed that this enzyme was probably derived from the succus entericus and was probably responsible for the considerable degree of protein digestion which has been demonstrated in children with pancreatic fibrosis (Frazer, McWeeney, Pover, Ross and Sammons, 1954). The present study suggests that the succus entericus is also responsible for the considerable degree of fat absorption which is found in this disease.

\section{Summary}

The fact that children with pancreatic fibrosis who have no pancreatic lipase at all can absorb a considerable proportion of dietary fat led us to 
investigate various sources of dietary and nondietary lipase in the gastro-intestinal tract.

Of the foods examined fresh unpasteurized milk was the only one which contained lipase: the enzyme was appreciably greater in human than in cow's milk. Pasteurization destroyed milk lipase and rapid loss of activity occurred at room temperature.

Lipase was present in the stools of these children but was absent in gastric juice and in cultures of intestinal organisms. It therefore appears that the enzyme is produced by the succus entericus.

The authors wish to thank Professor A. C. Frazer and Professor J. M. Smellie for their interest and advice. They are grateful to Dr. K. B. Rogers for cultures of intestinal organisms, to Dr. R. Astley for radiological assistance with duodenal intubations, and to Miss $M$. Cutler for technical assistance. This study was made with the help of a grant from the United Birmingham Hospitals Research Fund.
REFERENCES

Andersen, D. H. (1938). Amer. J. Dis. Child., 56, 344.

- (1945a). Ibid., 69, 141.

Anderson, C. Ibid., 69, 221. Sammons, H. G. and Smellie, J. M. (1952). Lancet, 1, 836.

Cregan, J. and Hayward, N. J. (1953). Brit. med. J., 1, 1356.

Davies, M. E. (1954). J. gen. Microbiol., 11, 37.

Frazer, A. C., McWeeney, D. J., Pover, W. F. R., Ross, C. A. C. and Sammons, H. G. (1955). Rec. Trav. chim., Pays-Bas. 74, 362. Sammons, H. G. and Thompson, M. D. (1955). To be published. and Stewart, H. C. (1939). J. Physiol., Lond., 95, 21, 23.

Freudenberg, E. (1929). Physiologie und Pathologie der Verdaunng

im Säuglingsalter. Berlin.

Kamer, J. H. van de, Bokkel Huinink, H. ten and Weyers, H. A. (1949). J. biol. Chem., 177, 347. Lowe, C. U., May, C. D. and Reed, S. C. (1949). Amer. J. Dis.

Ross, C. A. C. (1955). Archives of Disease in Childhood, 30, 316. Sammons, H. G., Ross, C. A. C. and Wood, W. A. (1955). Clin. Sci., 14, 157.

Schønheyder, F. and Volqvartz, K. (1944). Acta physiol. scand., 7, 376.

Shohl, A. T. (1948). J. Pediat., 32, 180.

Singer, H., Sporn, J. and Necheles, H. (1954). Gastroenterology, 26, 299.

Tomarelli, R. M., Charney, J. and Harding, M. L. (1949). J. Lab. clin. Med., 34, 428.

Wolman, I. J. (1943). Amer. J. med. Sci., 206, 770. 